\title{
PELATIHAN DAN PENDAMPINGAN PEMBUATAN MEDIA PEMBELAJARAN BERBASIS MULTIMEDIA INTERAKTIF
}

\author{
Hartono, Chandra Lesmana, Ryan Permana, Matsun \\ IKIP PGRI Pontianak \\ andra.hartono@gmail.com
}

\begin{abstract}
Abstrak: Program PKM ini bertujuan untuk meningkatkan: (1) keterampilan guru merancang dan mengembangkan media pembelajaran berbasis multimedia interaktif; (2) keterampilan guru dalam pelaksanaan pelatihan dan respon guru SMP N 8 Sungai Kakap Kabupaten Kubu Raya melalui kegiatan ini yang meliputi penggunaan media pembelajaran berbasis multimedia interaktif. Metode yang digunakan adalah adalah metode deskrptif. Langkah-langkah yang digunakan yaitu sosialisasi, ceramah, latihan dan pendampingan, evaluasi. Pelaksanaan dilakukan sebanyak 5 kali pertemuan, dimana pertemuan pertama berupa penyajian materi, dan dilanjutkan dengan pendampingan pembuatan media hingga selesai, dan terakhir dilakukan evaluasi berupa peserta mempresentasikan media yang telah dibuat dan respon peserta terhadap pelatihan melalui pengisian angket. Hasil yang diperoleh peserta dapat membuat media pembelajaran berbasis multimedia interaktif menggunakan software sothink swf easy. Hasil respon peserta melalui wawancara diperoleh hasil $100 \%$ peserta memberikan respon positif terhadap pernyataan positif yang dimintai tanggapan. Selain itu, 75\% peserta memberikan saran untuk terus melaksanakan kegiatan pelatihan ini secara berkala.
\end{abstract}

Kata Kunci: media, multimedia, interaktif

\begin{abstract}
The purposes of this community service program are to improve: (1) teacher skills in designing and developing interactive multimedia-based learning media; (2) the skills of teachers in the implementation of training and response of teachers in Sungai Nap Middle School $8 \mathrm{~N}$ Kubu Raya District through this activity which includes the use of interactive multimedia-based learning media. The method used is descriptive method. The steps used are socialization, lecture, training and mentoring, evaluation. The implementation was carried out in the five meetings. The first meeting was in the form of material presentation, and continued with assistance in making the media to completion, and finally an evaluation in the form of participants presenting the media that had been made and participants' responses to the training through filling out questionnaires. The results obtained by participants can make interactive multimedia-based learning media using Sothink Swf easy software. The results of the participants' responses through interviews showed that 100\% of participants responded positively to the positive statements asked for responses. In addition, $75 \%$ of participants gave suggestions to continue to carry out these training activities regularly.
\end{abstract}

Keywords: media, multimedia, interactive

\section{Pendahuluan}

Pendidikan nasional yang berdasarkan Pancasila dan Undang-undang Dasar Negara Republik Indonesia Tahun 1945 haruslah sesuai dengan tujuan pendidikan nasional. Dalam Undang-undang Dasar 1945 Pasal 31, ayat 5 menyebutkan bahwa, "Pemerintah memajukan ilmu pengetahuan dan teknologi dengan menjunjung tinggi nilai-nilai agama dan persatuan bangsa untuk kemajuan peradaban serta kesejahteraan umat manusia." Hal yang perlu digaris bawahi adalah memajukan ilmu pengetahuan dan teknologi yang bearti keduanya saling melengkapi dalam mencapai kemajuan itu sendiri. Terlebih lagi, kondisi saat ini yang sudah 
memasuki era globalisasi dituntut untuk melakukan percepatan dalam pemahaman pengetahuan dan teknologi.

Kemajuan ilmu pengetahuan dan teknologi secara global digambarkan dengan kemajuan teknologi informasi dan komunikasi (TIK). Hal itu bisa terlihat pada penyebaran informasi dan proses komunikasi saat ini yang tidak lagi dalam hitungan menit akan tetapi sudah bisa dikatakan per sekian detik. Selain itu, tampilan dan wujud informasi dan komunikasi itu sendiri sudah tidak lagi analog dan pasif akan tetapi sudah digital dan bersifat aktif dan interaktif. Menurut Darmawan (2011: 4) kemajuan teknologi informasi dan komunikasi dapat dilakukan pada bidang pendidikan. Lebih lanjut dikatakan ide-ide pembelajaran yang sulit dideskripsikan menjadi mudah melalui animasi-animasi yang menarik, kemudian dapat mempermudah simulasi proses-proses yang rumit.

Pendidikan yang merupakan bentuk usaha untuk menyiapkan peserta didik melalui kegiatan bimbingan, pengajaran, dan atau latihan bagi peranannya di masa yang akan datang haruslah menjadi pusat lahirnya kemajuan teknologi. Untuk mewujudkan hal tersebut, tentulah peserta didik harus dibiasakan dengan penggunaan teknologi, akan tetapi yang menjadi hambatan adalah pengetahuan guru akan teknologi. Padahal Wena (2016: 2) mengatakan guru adalah komponen penting dari tenaga kependidikan yang memiliki tugas untuk melaksanakan proses pembelajaran. Dengan demikian, guru haruslah terlebih dahulu memahami teknologi terutama teknologi dalam pembelajaran. Untuk yang lebih sederhana Wena (2016: 2) menambahkan guru harus mampu mengelola berbagai sumber daya yaitu dirinya sendiri dan media pembelajaran.

Pelaksanaan observasi dilakukan pada Sekolah Menengah Pertama Negeri 8 Kecamatan Sungai Kakap di Kabupaten Kubu Raya diperoleh bahwa sekolah tidak memiliki laboratorium pembelajaran yang berbasis IT, sehingga pembelajaran selalu dilaksanakan di kelas. Selain itu, pembelajaran juga masih dominan menggunakan media-media konvensional yaitu papan tulis dan buku, jarang sekali menggunakan media komputer. Lebih lanjut diperoleh informasi bahwa minimnya guru yang memahami penyusunan atau penggunaan media pembelajaran menggunakan komputer. Padahal menurut Darmawan (2011: 8) teknologi komputer dapat menjadi multimedia dalam pembelajaran yang artinya penggunaan aplikasi komputer dapat berfungsi lebih dari sebagai satu media.

Terbatasnya penggunaan media pembelajaran oleh guru mengakibatkan model pembelajaran yang diterapkan juga bersifat terbatas pada aktifitas fisik saja, akan sulit sekali untuk merumuskan model pembelajaran yang memadukan segala aspek. Menurut Joice dkk (Trianto, 2017: 52) model pembelajaran adalah suatu perencanaan atau pola pembelajaran yang bertujuan menentukan materi pembelajaran salah satunya termuat dalam programprogram media komputer, mengingat suatu model berfungsi mengarahkan perencanaan pembelajaran yang membantu peserta didik mencapai berbagai tujuan. Sehingga tidak dapat dipungkiri lagi jika guru di SMP Negeri 8 Sungai Kakap sedikit sekali yang dapat menggunakan model pembelajaran yang memanfaatkan program-program komputer. Minimnya penggunaan media pembelajaran yang bebasis IT di sekolah tersebut menimbulkan kekhawatiran yang akan didapatkan oleh peserta didik sebagai akibat dari kondisi yang sedang terjadi. Hal tersebut dapat 
berupa kurang familiarnya fungsi-fungsi IT bagi peserta didik, sehingga tujuan pendidikan untuk menyiapkan peserta didik sebagai problem solver di masyarakat tidak akan tercapai. Apalagi menurut Sani (2017: 9) tantangan di masa yang akan datang, salah satunya adalah kecenderungan penggunaan IT di kehidupan era globalisasi, sehingga masalah tersebut harus secara kontinyu diupayakan untuk diselesaikan.

Oleh karena itu, tim pengabdian pada masayarakat IKIP PGRI Pontianak melakukan komunikasi secara intensif dengan pengelola SMP Negeri 8 Sungai Kakap untuk mendapatkan solusi dari permasalahan tersebut. Lebih lanjut komunikasi menghasilkan suatu keputusan bahwa perlu diadakannya suatu pelatihan dan pendampingan pembuatan media pembelajaran.

Media pembelajaran secara umum adalah alat bantu proses belajar mengajar. Segala sesuatu yang dapat dipergunakan untuk merangsang pikiran, perasaan, perhatian dan kemampuan atau keterampilan belajar sehingga dapat mendorong terjadinya proses belajar. Batasan ini cukup luas dan mendalam mencakup pengertian sumber, lingkungan, manusia dan metode yang dimanfaatkan untuk tujuan pembelajaran / pelatihan. Dalam proses aktif, media pembelajaran berperan sebagai salah satu sumber belajar bagi siswa. Artinya melalui media peserta didik memperoleh pesan dan informasi sehingga membentuk pengetahuan baru pada siswa. Dalam batas tertentu, media dapat menggantikan fungsi guru sebagai sumber informasi/pengetahuan bagi peserta didik. Media pembelajaran sebagai sumber belajar merupakan suatu komponen sistem pembelajaran yang meliputi pesan, orang, bahan, alat, teknik, dan lingkungan, yang dapat mempengaruhi hasil belajar siswa sehingga proses pembelajaran menjadi efektif.

Pembelajaran yang efektif dapat dilihat dengan penggunaan media pembelajaran pada saat proses pembelajaran. Seluruh materi pembelajaran juga dapat memanfaatkan media pembelajaran berbasis multimedia. Oleh sebab itu pembelajaran berbasis multimedia menjadi semakin umum. Meskipun memiliki keterbatasan dan tentu tidak harus dilihat sebagai pengganti untuk interaksi langsung yang memiliki banyak keuntungan untuk pengembangan guru profesional.

Multimedia merupakan salah satu bentuk teknologi komputer yang saat ini banyak digunakan dalam bidang pendidikan. Multimedia mencakup bebagai media dalam satu perangkat lunak (software). Menurut beberapa pakar, diantaranya Furt, Haffors, Thomson dan Jayant (Munir, 2001: 13) mendefinisikan multimedia sebagai gangunagn antara berbagai media seperti teks, numerk, frafik, gambar, animasi, video, fotografi, suat dan data yang dikendalikan dengan program komputer (dalam satu software digital) serta mempunyai kemampuan interaktif, menjadi salah satu alternatif yang baik sebagai alat bantu dalam pembelajaran.

Elemen-elemen multimedia yang menggabungkan beberapa komponen seperti warna, teks, animasi, gambar/grafik, suara dan video sangat menunjang dalam memenuhi kebutuhan belajar siswa yang memiliki kemampuan kognitif yang berbeda. Konsep multimedia menurut Mayer (2001) meliputi tiga level, yaitu, pertama level teknis yang berkaitan dengan alat-alat teknik: alat-alat ini dapat dianggap sebagai kendaraan pengangkut tanda-tanda (signs); kedua, level semiotik yang berkaitan dengan bentuk representasi (yaitu teks, gambar atau grafik); bentuk representasi ini dapat dianggap sebagai jenis tanda (type of signs); ketiga, level sensorik 
yaitu berkaitan dengan saluran sensorik yang berfungsi untuk menerima tanda (signs). Bila dalam suatu aplikasi multimedia, pemakai (user) diberikan suatu kemampuan untuk mengontrol elemen-elemen yang ada, maka multimedia tersebut dinamakan interactive multimedia (multimedia interaktif).

Multimedia juga menyediakan peluang bagi pendidik untuk mengembangkan teknik pembelajaran sehingga menghasilkan hasil yang maksimal. Demikian juga bagi peserta didik, dengan multimedia diharapkan mereka akan lebih mudah untuk menentukan dengan apa dan bagaimana peserta didik dapat menyerap informasi secara cepat dan efisien. Sumber informasi tidak terfokus pada teks dari buku melainkan lebih luas cakupan informasi yang didapat. Kemampuan teknologi multimedia yang semakin baik dan berkembang akan menambah kemudahan dalam mendapatkan pengetahuan peserta didik. Pengembangan teori dan konsep tentang pembuatan media pembelajaran berbasis multimedia ini berbentuk kegiatan workshop/ pelatihan untuk melatih softskill guru dalam membuat media pembelajaran. Dengan workshopl pelatihan diharapkan guru mampu menerapkan dan mengaplikasikan teori dan konsep tentang kemampuan penggunaan media pembelajaran berbasis multimedia interaktif.

\section{Metode}

Metode yang digunakan dalam Program Kemitraan Masyarakat (PKM) ini adalah metode deskrptif. Metode deskriptif merupakan suatu cara pemecahan masalah dengan menggunakan celah tertentu untuk mengetahui keadaan suatu subjek dari objek yang berdasarkan pada suatu kenyataan yang aktual yang terjadi pada saat penelitian dilaksanakan. Untuk mendeskripsikan kegiatan pelaksanaan PKM pada setelah diberikanya pelatihan pembuatan media pembelajaran berbasis multimedia interaktif.

Kegiatan dilaksanakan di SMP Negeri 8 Sungai Kakap, Kabupaten Kubu Raya, alasan pemilihan lokasi tersebut karena permasalahan yang dihadapi oleh sekolah yaitu agar guru-guru menerima informasi dalam pemanfaatan aplikasi-aplikasi di dalam komputer yaitu pemanfaatan aplikasi media pembelajaran berbasis multimedia interaktif.

Kegiatan dalam program PKM ini meliputi pemberian workshop/ pelatihan kepada guru dilingkungan sekolah selaku objek, serta pembimbingan pembuatan produk hingga produk tersebut selesai dan dapat digunakan. Secara rinci, langkah-langkah yang dilakukan dalam pelaksanaan kegiatan ini adalah sebagai berikut:

1. Observasi lapangan untuk memperoleh data awal tentang permasalahan yang dihadapi oleh kedua mitra

2. Analisis kebutuhan mitra dan menawarkan solusi penyelesaian

3. Membuat perancangan sistem

4. Membuat materi yang berkenaan dengan pengembangan media pembelajaran berbasis multimedia interaktif menggunakan aplikasi Sothink SWF.

5. Melakukan pelatihan pengenalan aplikasi Sothink SWF.

6. Melakukan workshop penggunaan aplikasi Sothink SWF dalam membuat media pembelajaran berbasis multimedia interaktif. 
7. Melakukan pendampingan kepada kedua mitra dalam pembuatan media pembelajaran berbasis multimedia interaktif menggunakan aplikasi Sothink SWF.

\section{Hasil dan Pembahasan}

Kegiatan sedang dilaksanakan yaitu di SMP Negeri 8 Sungai Kakap, Kabupaten Kubu Raya. Kegiatan dalam program PKM ini meliputi pemberian workshop/ pelatihan kepada guru di masing-masing sekolah tersebut, serta pembimbingan pembuatan produk hingga produk tersebut selesai dan dapat digunakan seperti yang diharapkan. Adapun kegiatan meliputi:

1. Observasi lapangan untuk memperoleh data awal tentang sarana dan prasarana pendukung pelatihan atau workshop termasuk waktu yang dapat digunakan untuk pelatihan. Kegiatan observasi ini dilaksanakan pada tanggal 01 Maret 2018. Adapun data yang diperoleh adalah sarana dan prasarana yang disediakan oleh sekolah mitra meliputi:

a. Tempat pelatihan menggunakan laboratorium sekolah

b. Soundsystem

c. LCD Proyektor

d. Laptop yang dimiliki masing-masing peserta

e. Peralatan pendukung lainnya.

2. Analisis kebutuhan lain untuk pelatihan dan memperoleh solusinya meliputi jadwal pelaksanaan kegiatan sebanyak 5 kali pertemuan, konsumsi kegiatan selama pelatihan berlangsung, dan peserta pelatihan yang memiliki komitmen untuk kontinyu menjadi peserta pelatihan. Peserta dipilih berdasarkan semangat guru untuk mempelajari pembuatan media pembelajaran berbasis multimedia interaktif dan persepsi guru mengenai media pembelajaran berbasis multimedia interaktif. Sembilan orang peserta menyatakan selalu menggunakan media dalam melaksanakan pembelajaran, akan tetapi delapan dari sembilan orang tersebut tidak pernah menggunakan media pembelajaran berbasis multimedia selain Ms. Power Point. Hal ini menunjukkan media sering digunakan dalam pembelajaran, hanya saja belumlah interaktif.

3. Membuat perancangan sistem dilakukan dengan koordinasi antar anggota tim pelaksana berdasarkan hasil observasi lapangan dan analisis kebutuhan lain. Perancangan sistem meliputi susunan acara, pengisi acara, hingga tugas-tugas anggota tim. Susunan pelaksanaan kegiatan terdiri dari pembukaan, pelatihan, pendampingan, presentasi dan penutup.

a. Pembukaan, dipandu oleh pembawa acara yaitu Matsun, S.Si, M.Pd yang merupakan tim pembantu lapangan. Kegiatan dimulai dengan membuka acara pembukaan yaitu dengan mengucapkan Basmalah. Kemudian, kata sambutan dari ketua pelaksana yaitu Chandra Lesmana, S.Kom, M.Pd dan dilanjutkan dengan sambutan dan membuka kegiatan pelatihan oleh Ketua Mitra yaitu Kepala Sekolah di masing-masing sekolah. Kegiatan pembukaan ini diakhiri dengan Doa.

b. Pelatihan dilakukan oleh ketua pelaksana bersama anggota tim dan dibantu oleh mahasiswa. Pelatihan dimulai dengan penyampaian materi yaitu pentingnya media 
dalam pembelajaran. penyusunan media pembelajaran yang menarik, dan teori-teori yang mendukung. Kemudian, tehknik penyusunan media interaktif yaitu Sothink SWF easy. Diakhiri dengan Presentasi media yang dibuat oleh peserta.

c. Pendampingan berupa kegiatan mendampingi peserta pelatihan dalam membuat media pembelajaran berbasis multimedia interaktif menggunakan aplikasi Sothink SWF Easy. Kegiatan ini juga dilakukan oleh semua anggota tim pelaksana kegiatan pelatihan. Pendampingan dilakukan hingga peserta menghasilkan suatu media pembelajaran berbasis multimedia interaktif menggunakan aplikasi sothink SWF easy secara utuh.

d. Presentasi direncanakan akan dilakukan oleh peserta, yaitu mempresentasikan media pembelajaran berbasis multimedia interaktif menggunakan aplikasi sothink SWF easy yang telah dibuat selama pendampingan. Presentasi dilakukan dihadapan para peserta yang lain dan tim pelaksana.

e. Penutup sebagai akhir dari kegiatan pelatihan yaitu dipandu oleh pembawa acara dengan susunan acara ucapan terima kasih kepada mitra oleh ketua pelaksana, kemudian kesan dan pesan sekaligus menutup kegiatan pelatihan oleh ketua mitra.

4. Membuat materi yang berkenaan dengan pengembangan media pembelajaran berbasis multimedia interaktif menggunakan aplikasi Sothink SWF. Materi disusun dalam bentuk buku panduan pembuatan media pembelajaran berbasis multimedia interaktif menggunakan aplikasi sothink SWF.

5. Kegiatan diawali dengan pembukaan yang dipandu oleh pembawa acara yaitu Matsun, S.Si, M.Pd., Pembukaan diawali dengan mengucapkan Basmalah, mengingat semua peserta beragama islam. Kemudian kata sambutan dari ketua pelaksana yaitu Chandra Lesmana, S.Kom, M.Pd dimana hal yang disampaikan adalah permasalahan-permasalahan yang ditemui pada saat menganalisis kondisi mitra, sehingga perlu adanya kerjasama dari mitra untuk menyelesaikan permasalahan yang muncul tersebut bersama-sama tim pelaksana kegiatan. Selanjutnya sambutan sekaligus membuka kegiatan oleh Ketua mitra dalam hal ini kepala sekolah, dimana sambutan yang disampaikan adalah ucapan terima kasih karena telah bersedia untuk membantu mitra dalam menyelesaikan permasalahan-permasalahan yang ada. Kemudian diakhiri dengan doa agar kegiatan pelatihan diberkahi dan diridhai oleh Allah SWT.

6. Melakukan pelatihan pengenalan aplikasi Sothink SWF sebanyak satu kali pertemuan dengan jumlah peserta 12 orang yang disampaikan oleh Chandra Lesmana, S.Kom, M.Pd. Materi yang disampaikan mulai dari teori mengenai media dalam pembelajaran, proses instalasi, manfaat dan keunggulan software, fungsi masing-masing toolbar, hingga simulasi contoh pembuatan media pembelajaran secara singkat, demonstrasi penggunaan media pembelajaran berbasis multimedia interaktif menggunakan aplikasi sothink SWF. Pelatihan dibuka oleh Kepala Sekolah Mitra bersama Tim PKM IKIP PGRI Pontianak 


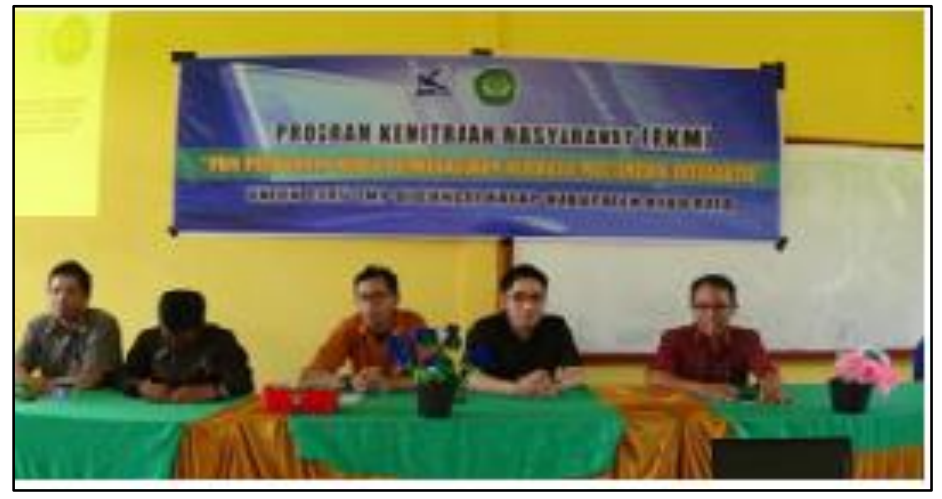

Gambar 1. Pembukaan Pelatihan di SMP N 8 Sungai Kakap

7. Melakukan workshop berupa pendampingan penggunaan aplikasi Sothink SWF Easy dalam membuat media pembelajaran berbasis multimedia interaktif. Tiap-tiap peserta diminta untuk membuat media pembelajaran sesuai dengan masing-masing mata pelajaran yang diampu. Peserta didampingi oleh tim dalam membuat media pembelajaran. Dimulai dengan proses intalasi di masing-masing laptop para peserta, dimana masing-masing anggota tim melakukan penginstakn 3-4 laptop. Peserta menyiapkan lembar kerja dengan menambahkan animasi-animasi yang sesuai dengan selera masing-masing. Proses pembuatan media selanjutnya dilakukan oleh peserta dilakukan secara mandiri dengan didampingi oleh anggota tim pelatih.

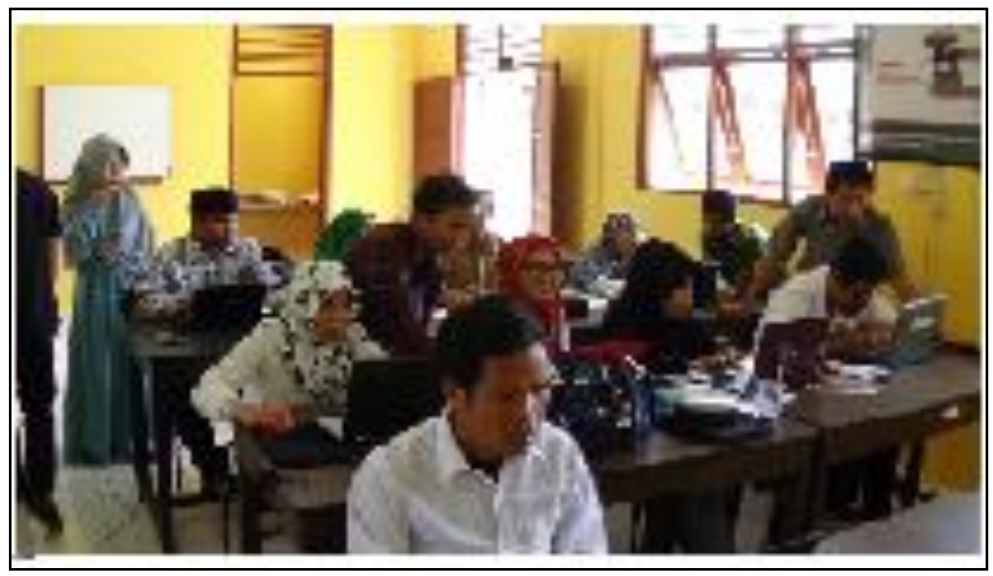

Gambar 2. Pelaksanaan Pendampingan Pelatihan

Peserta sebelum diberikan pelatihan sudah sering menggunakan media pembelajaran. Sebagian peserta menyatakan media pembelajaran dapat dibuat dengan mudah. Setiap materi pembelajaran dapat disajikan ke dalam media berikut evaluasinya. Terlebih lagi, media pembelajaran yang diharapkan berbasis interaktif. Seluruh responden setuju untuk selalu menggunakan media dalam pembelajaran dan setiap materi dapat disajikan ke dalam media pembelajaran, kemudian sebagian besar responden tidak setuju jika pembuatan media pembelajaran dikatakan mudah dan media pembelajaran berbasis multimedia interaktif.

Seluruh peserta belum pernah mengenal media pembelajaran selain Ms. power point. Sedangkan pada pernyataan yang lebih spesifik yaitu pada media pembelajaran berbasis 
multimedia hampir semua responden menyatakan belum pernah baik menggunakan maupun membuat media pembelajaran selain Ms. Power Point. Lebih lanjut, mengenai sothink SWF semua peserta belum pernah membuat maupun menggunakan media pembelajaran interaktif dengan software tersebut. Selain itu, untuk mengetahui respon peserta setelah diberikan pelatihan pembuatan media pembelajaran berbasis multimedia interaktif menggunakan sothink SWF diberikan angket respon yang berisi pernyataan-pernyataan seputar sothink SWF dan rangkaian seputar pelatihan.

Setelah pelatihan dan pendampingan, peserta merasa materi yang disajikan dapat menambah wawasan saya tentang pembuatan media pembelajaran berbasis multimedia interaktif sothink swf easy. Penyajian materi tentang pembuatan media pembelajaran berbasis multimedia interaktif sothink swf easy cukup interaktif. Bahan pelatihan dapat membantu saya dalam meningkatkan wawasan tentang pembuatan dan penggunaan media pembelajaran berbasis multimedia interaktif sothink swf easy. Kegiatan workshop dapat meningkatkan keterampilan pembuatan media pembelajaran berbasis multimedia interaktif sothink swf easy. Kegiatan workshop dapat meningkatkan kemampuan mengembangkan proses dan evaluasi pembelajaran. Pelayanan administrasi untuk peserta sudah memadai. Pelayanan konsumsi untuk peserta sudah memadai. Setelah kegiatan ini saya akan berusaha membuat media pembelajaran berbasis multimedia interaktif sothink swf easy agar pembelajaran menjadi efektif dan menarik di Sekolah. Kegiatan ini dapat membantu saya untuk meningkatkan profesionalisme. Komentar dan saran yang diberikan oleh peserta pelatihan yang diberikan sudah baik dan harapannya pelatihan terus dilakukan secara berkala. Dari 12 peserta terdapat 9 orang memberikan kecenderungan memberikan kritik dan saran yang hampir mirip seperti gambar 5.3.

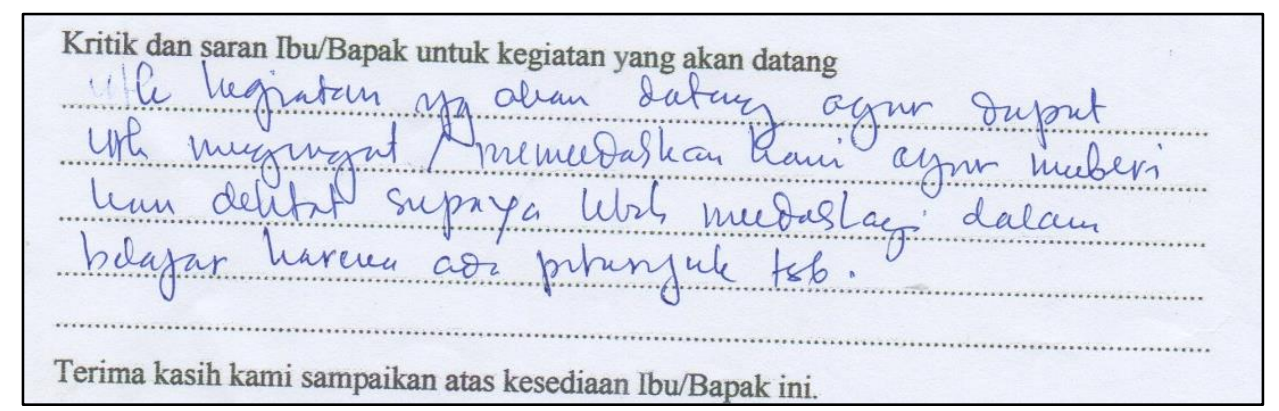

Gambar 3. Kritik dan Saran dari Peserta Pelatihan

\section{Kesimpulan}

Pelatihan dan pendampingan pembuatan media pembelajaran berbasis multimedia dengan menggunakan sothink SWF easy pada SMP Negeri 8 Sungai Kakap dengan peserta pelatihan adalah guru di sekolah mitra tersebut. Untuk tahap awal, dilakukan persiapan pelatihan mulai dari pemahaman para tim pendamping peserta terhadap aplikasi sothink SWF easy, penyusunan bahan ajar pelatihan, pembuatan kesepakatan jadwal pelatihan, sarana dan prasarana, hingga pelaksanaan pelatihan yang dilaksanakan pada mitra pengabdian yaitu SMP Negeri 8 Sungai Kakap. Pelaksanaan pelatihan menghasilkan media pembelajaran yang dibuat 
oleh peserta, hal ini menunjukkan pelatihan dilaksanakan sampai pada tahap peserta memiliki skill membuat media pembelajaran berbasis multimedia dengan menggunakan sothink SWF easy. Oleh karena itu, pelatihan yang telah dilaksanakan pada mitra pertama sudah terlaksana dengan baik walaupun terdapat hambatan yang tidak signifikan. Hal tersebut didukung dengan hasil respon peserta yang dituangkan melalui wawancara diperoleh hasil $100 \%$ peserta memberikan respon positif terhadap pernyataan positif yang dimintai tanggapan. Selain itu, $75 \%$ peserta memberikan saran untuk terus melaksanakan kegiatan pelatihan ini secara berkala.

\section{Ucapan Terima Kasih}

Kegiatan pelatihan dan pendampingan pembuatan media pembelajaran berbasis interaktif dengan menggunakan sothink SWF easy ini atas dukungan dana dari DRPM Kemenristek Dikti dan dukungan administratif serta sarana dan prasarana kegiatan oleh IKIP PGRI Pontianak dan SMP Negeri 8 Sungai Kakap.

\section{Referensi}

Darmawan, Deni. 2011. Teknologi Pembelajaran. Bandung: Remaja Rosdakarya.

Wena, Made. 2016. Strategi Pembelajaran Inovatif Kontemporer Suatu Tinjauan Konseptual Operasional. Jakarta: Bumi Aksara.

Trianto. 2017. Model Pembelajaran Terpadu: konsep, strategi, dan implementasinya dalam kurikulum tingkat satuan pendidikan (KTSP). Jakarta: Bumi Aksara.

Sani, Abdullah Ridwan. 2017. Pembelajaran Saintifik unruk Implementasi Kurikulum 2013. Jakarta: Bumi Aksara. 